\title{
Model Aplikasi Gamification pada Smartphone untuk Pembelajaran di Kelas
}

\author{
Gani Suryo Buwono' ${ }^{1)}$, Teduh Dirgahayu' \\ Magister Informatika, Fakultas Teknologi Industri, Universitas Islam Indonesia \\ Jl. Kaliurang km 14, 5 Sleman, Yogyakarta, 55584, Indonesia ${ }^{1)}$ \\ Jurusan Informatika, Universitas Islam Indonesia \\ Jl. Kaliurang km 14, 5 Sleman, Yogyakarta, 55584, Indonesia ${ }^{2)}$ \\ E-Mail:17917107@students.uii.ac.id ${ }^{l}$,teduh.dirgahayu@uii.ac.id ${ }^{2}$
}

\begin{abstract}
ABSTRAK
Pembelajaran di kelas yang tidak interaktif dapat disebabkan mayoritas mahasiswa yang tidak mampu memahami materi dari dosen, sehingga tidak muncul umpan balik dari mahasiswa. Hal ini menjadikan dosen tidak bisa secara efektif mengukur tingkat keberhasilan pembelajaran. Makalah ini mengusulkan model aplikasi gamification pada smartphone untuk pembelajaran di kelas. Aplikasi dirancang untuk menunjang interaksi dosen dan mahasiswa di kelas. Proses perancangan aplikasi dilakukan sebagai penelitian desain melalui beberapa tahap, yakni identifikasi masalah, menentukan tujuan solusi, desain dan pengembangan solusi, demonstrasi solusi, evaluasi, dan komunikasi. Penelitian ini menggunakan metode kualitatif untuk dosen dan metode kuantitatif untuk mahasiswa. Metode kualitatif menggunakan wawancara untuk mengukur kesiapan dosen dalam menggunakan TI serta pengalaman gamifikasi dalam pembelajaran. Metode kuantitatif menggunakan kuesioner COLLES yang dikombinasikan dengan skala penilaian kesiapan Aydin dan Tasci. Kuesioner COLLES digunakan untuk mengukur capaian mutu, pengetahuan dan keaktifan mahasiswa dalam pembelajaran berbantuan aplikasi. Pengukuran dilakukan pada enam variabel, yaitu Tutor Support (nilai 3.98), Peer Support (3.94), Relevance (3.65), Interactivity (3.72), Reflection (3.42) dan Interpretation (3.57). Nilai rata-rata pengukuran berada pada rentang antara 3.5 dan 4.2, yang bermakna "siap namun perlu sedikit perbaikan". Hasil wawancara dan kuesioner tersebut menjadi dasar perancangan model aplikasi gamification pada smartphone untuk pembelajaran di kelas.
\end{abstract}

Kata kunci: pembelajaran interaktif, aplikasi gamification, smartphone, pembelajaran di kelas, COLLES

\section{A Model of Smartphone's Gamification Application for Classroom Learning}

\begin{abstract}
Uninteractive classroom learning can be caused by the majority of students who cannot understand material from lecturers, so there is no feedback from students. This makes the lecturers unable to effectively assess the learning successfulness. This paper proposes a model of gamification application on smartphones for classroom learning. The application is to support the interaction of lecturers and students in a classroom. The application design process is done as a design research through several stages, i.e. identify problems, define objectives of a solution, design and development, demonstration, evaluation, and communication. The research uses a qualitative method to lecturers and quantitative method to students. The qualitative method uses interviews to measure the readiness of lecturers in using IT and their gamification experience in learning. The quantitative method uses COLLES questionnaire combined with Aydin and Tasci's readiness assessment scale. The COLLES questionnaire measures the quality, knowledge and activeness of students in application-assisted learning. Measurements were made on six variables, namely Tutor Support (score 3.98), Peer Support (3.94), Relevance (3.65), Interactivity (3.72), Reflection (3.42) and Interpretation (3.57). The average score is on a range between 3.5 and 4.2, that means "ready but needs a little improvement". The results of the interviews and questionnaires form the basis for designing a gamification application model on smartphones for classroom learning.
\end{abstract}

Keywords: interactive learning, gamification application, smartphone, classroom learning, COLLES 


\section{Pendahuluan}

Proses pembelajaran di perguruan tinggi melibatkan interaksi antara dosen dan mahasiswa. Tujuan dari interaksi dalam proses pembelajaran yang yaitu mengasah dan menumbuhkan potensi setiap mahasiswa agar mampu untuk mengikuti proses pembelajaran dengan efektif (Rifai, 2011). Interaksi yang tidak berjalan dapat mengakibatkan tidak berjalannya komunikasi dalam proses pembelajaran, imbasnya interaksi dalam kelas hanya akan bersifat satu arah dan tidak akan mencapai hasil pokok proses pembelajaran yaitu keaktifan mahasiswa salah satunya berupa umpan balik (Effendy, 2008). Metode pembelajaran interaktif diterapkan dengan maksud membuat mahasiswa mampu berperan aktif dalam proses pembelajaran salah satunya dengan menyampaikan umpan balik pada materi yang disampaikan oleh dosen (Krusche, Seitz, Börstler, \& Bruegge, 2017).

Proses pembelajaran interaktif di kelas tidak akan mencapai hasil maksimal jika semua mahasiswanya tidak mampu menyerap materi dengan baik. Kim, Cho, \& Jung (2009) menyatakan bahwa proses pembelajaran dengan model lama sulit mencapai kondisi pembelajaran interaktif, sehingga ilmu yang disampaikan oleh dosen tidak semuanya mampu diserap mahasiswa dengan baik. Imbas dari kondisi tersebut yaitu dosen sulit mengukur tingkat keberhasilan pembelajaran karena hasil evaluasi pembelajaran yang tidak maksimal (Sanjaya, 2008).

Munculnya berbagai teknik pembelajaran interaktif disertai kemajuan teknologi Informasi (TI) diharapkan mampu menghasilkan pembelajaran yang aktif. Proses pembelajaran interaktif telah dilakukan dengan menggunakan metode quiz real-time, namun belum mampu melihat efek serta pemahaman materi yang diajarkan (Ferrándiz, Puentes, Moreno, \& Flores, 2016). Penggunaan metode pembelajaran lainnya yaitu metode Real-time Interaction Platform masih memerlukan beberapa peningkatan di berbagai fungsinya (Wang, $\mathrm{Hu}, \&$ Lin, 2019). Metode Smartphone with collaborative learning yaitu pembelajaran dengan memanfaatkan Student Response Systems (SRS) melalui socrative dan smartphone dapat mewujudkan lingkungan belajar yang aktif, namun hasil datanya masih terbatas pada penggunanya saja (Awedh, Mueen, Zafar, \& Manzoor, 2015). Metode Smartphone-Supported Collaborative Learning System (SSCLS) dapat digunakan untuk mencapai tujuan pembelajaran yang efektif dari sisi partisipasi dan interaksi mahasiswa dalam kelas, namun kelemahannya masih sangat bergantung pada kemampuan dosen dalam menggunakan Delphi untuk mencapai hasilnya (Chuang, 2015). Metode lain memanfaatkan Social Network Service (SNS) platform yakni twitter untuk menyampaikan ceramah dari dosen dan ditanggapi oleh mahasiswa pada kelas besar. Kelemahan metode ini adalah ketersediaan layanan internet yang harus stabil dalam menunjang proses pembelajaran (Kim, Jeong, Ji, Lee, Kwon, \& Jeon, 2014). Smartphone dinilai tepat sebagai perangkat pembelajaran interaktif di dalam kelas. Pemilihan smartphone sendiri sebagai pendukung pembelajaran berdasarkan hasil survei Google yang mengindikasikan bahwa $43 \%$ orang Indonesia mempunyai ketergantungan pada smartphone dalam mendukung kegiatan kesehariannya (Wijaya, 2015). Smartphone yang memiliki banyak fungsi ini penggunaannya dapat diarahkan ke proses pembelajaran seperti latihan soal bagi mahasiswa dan mengerjakan tugas individu maupun kelompok di kelas (Grinols \& Rajesh, 2014).

Metode pembelajaran interaktif dengan memanfaatkan Teknologi Informasi (TI) mulai menerapkan metode gamification seperti pada Kahoot. Gamification adalah sebuah proses game yang bertujuan meningkatkan motivasi kinerja melalui peningkatan keterlibatan pengguna yang didasari pada rasa antusias dalam menjalankan tantangan tersebut. Hasil dari proses ini dapat berupa pengalaman pengguna dan hasil dari keterlibatan pengguna yang berbentuk nilai atau capaian 
selama proses (Huotari \& Hamari, 2012). Gamification dalam dunia pendidikan tidak sepenuhnya mengambil segi permainannya saja, namun hanya mengambil sisi mekanisme permainan yang berhubungan dengan materi pembelajaran (Huang \& Soman, 2013). Penerapan gamification itu sendiri pada proses pembelajaran mampu meningkatkan pemahaman serta motivasi belajar (Barata, Gama, Jorge, \& Gonçalves, 2013).

Makalah ini bertujuan untuk menghasilkan model aplikasi gamification pada smartphone untuk pembelajaran di kelas yang mampu menunjang kebutuhan interaksi dosen dan mahasiswa. Hasilnya diharapkan dapat dapat menghasilkan model gamification untuk pembelajaran di kelas sekaligus memberikan kontribusi dan kemudahan dalam proses pembelajaran yang interaktif dan mampu meningkatkan antusias dan interaksi mahasiswa saat pembelajaran di kelas serta dari sisi dosen agar terbantu dalam melakukan pemberian materi serta penilaian langsung hasil pembelajaran di kelas. Penelitian ini mengambil studi kasus di Universitas Islam Indonesia.

\section{Metodologi}

\subsection{Jenis dan Objek Penelitian}

Penelitian ini dikerjakan dalam bentuk penelitian desain dengan menerapkan metode kualitatif dan kuantitatif. Metode kualitatif digunakan untuk mendapatkan dan menganalisis data hasil wawancara kepada mahasiswa dan dosen di lingkungan Universitas Islam Indonesia yang terdiri dari program studi Psikologi, program studi Informatika, program studi Pendidikan Agama Islam dan program studi pendidikan Kimia. Metode kuantitatif berupa kuesioner untuk mendapatkan data dengan sumber informasi berasal dari mahasiswa terkait pembelajaran di kelas dan pengalaman pembelajaran dengan TI.

\subsection{Penelitian Desain}

Jenis penelitian yang diterapkan pada penelitian ini yaitu penelitian desain dengan beberapa tahapan yang harus dijalankan secara sistematis dan baik, seperti ditunjukkan pada Gambar 1.

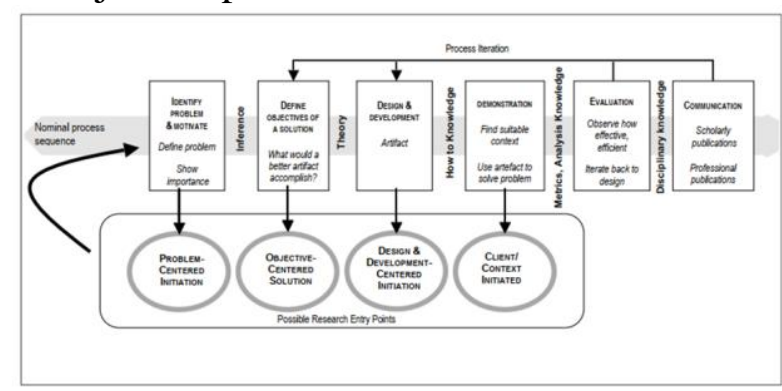

Gambar 1. Design Science Research Methodology (DSRM) Process Model (Peffers, Tuunanen, Rothenberger, \& Chatterjee, 2007)

\subsubsection{Identifikasi Masalah}

Pada tahapan ini, dilakukan pencarian kelemahan pada sistem-sistem yang ada dan permasalahan yang ditemukan adalah permasalahan interaktif antara dosen dan mahasiswa yang terkendala sehingga memerlukan sarana yang mampu meningkatkan keikutsertaan mahasiswa dalam proses pembelajaran. Pendekatan untuk mendapatkan informasi menggunakan metode wawancara untuk dosen dan pembagian kuesioner untuk mahasiswa. Kuesioner untuk mahasiswa berdasarkan konsep Constructivist On-Line Learning Environment Survey (COLLES) yang terdiri dari enam variabel, yaitu Tutor Suport, Peer Support, Relevance, Interactivity, Reflection, Interpretation. Tujuan penerapan COLLES pada kuesioner adalah untuk mengukur sejauh mana pembelajaran on-line mampu meningkatkan mutu dan pengetahuan mahasiswa serta mengukur keaktifan mahasiswa dalam proses pembelajaran (Taylor \& Maor, 2000).

Penilaian kuesioner dalam COLLES memakai skala Likert dengan 5 (lima) skala, yaitu Hampir Tidak Pernah (1), Jarang (2), Terkadang (3), Sering (4) dan Hampir Selalu (5). Kuesioner digunakan untuk menemukan bentuk interaksi, kebutuhan serta kemungkinan permasalahan yang bisa terjadi di kelas. Enam variabel dalam kuesioner berdasarkan COLLES pada penelitian ini dapat dilihat pada Tabel 1 . 
Tabel 1. Variabel Penelitian

\begin{tabular}{|c|c|c|}
\hline No. & Variabel & Indikator \\
\hline \multirow[t]{3}{*}{1} & Tutor Support & 1. Respon cepat dosen \\
\hline & & 2. Dukungan dosen terhadap partisipasi mahasiswa \\
\hline & & 3. Dosen memberi umpan balik hasil pekerjaan mahasiswa \\
\hline \multirow[t]{5}{*}{2} & Peer Support & 1. Kerjasama dengan mahasiswa lain \\
\hline & & 2. Berbagi informasi dengan mahasiswa lain \\
\hline & & 3. Diskusi soal gagasan dengan mahasiswa lain \\
\hline & & 4. Kerja kelompok \\
\hline & & 5. Kompetisi dengan mahasiswa lain \\
\hline \multirow[t]{2}{*}{3} & Relevance & 1. Pemahaman materi perkuliahan \\
\hline & & 2. Tugas dan pengalaman di luar kuliah \\
\hline \multirow[t]{3}{*}{4} & Interactivity & 1. Pengukuran pemahaman pada materi kuliah \\
\hline & & 2. Kemudahan memilih materi kuliah \\
\hline & & 3. Tantangan pada system peringkat dalam kuis/ tugas \\
\hline \multirow[t]{4}{*}{5} & Reflection & 1. Menyampaikan ketidakpahaman terkait materi \\
\hline & & 2. Memecahkan masalah sendiri \\
\hline & & 3. Mampu mengambil keputusan dan jawaban dengan cepat \\
\hline & & 4. Evaluasi dan strategi belajar \\
\hline \multirow[t]{3}{*}{6} & Interpretation & 1. Menilai prioritas tugas \\
\hline & & 2. Langsung berdiskusi dengan dosen \\
\hline & & 3. Dapat melihat hasil perkuliahan dengan cepat \\
\hline
\end{tabular}

Hasil penilaian dari variabel didapatkan dari nilai rata-rata pada setiap indikator, kemudian untuk nilai indikator sendiri didapat dari rata-rata tiap pertanyaan pada kuesioner. Hasil rata-rata variabel serta nilai indikator kemudian dimasukkan pada skala pengukuran adaptasi model Aydın \& Tasci (2005), seperti pada Gambar 2.

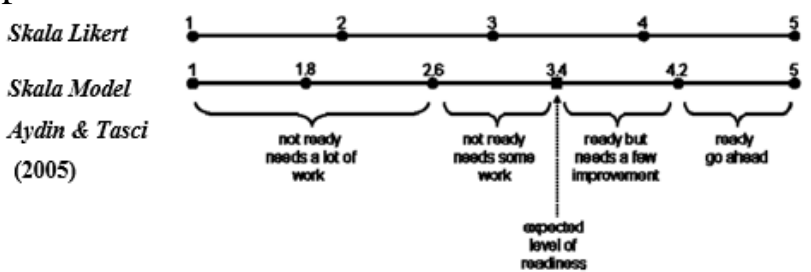

Gambar 2. Skala penilaian Model Aydın \& Tasci (2005)

\subsubsection{Menentukan Tujuan dari Solusi}

Tahapan ini menetapkan arah tujuan solusi terhadap masalah yang ada. Solusi yang akan dibuat adalah merancang model aplikasi pembelajaran interaktif dengan metode gamification pada smartphone. Tujuan aplikasi ini adalah untuk meningkatkan keaktifan mahasiswa dalam kegiatan pembelajaran, serta untuk memudahkan dosen dalam melakukan penilaian karena semua kegiatan sudah tercatat dalam aplikasi.

\subsubsection{Desain dan Pengembangan}

Pada tahapan desain dan pengembangan ini, system dirancang dengan dasar masalah yang sudah ditemukan pada tahapan sebelumnya. Aplikasi ini akan terbagi dua kategori pengguna yaitu dosen dan mahasiswa. Dalam penelitian ini data yang diperlukan yaitu:

1. Data kebutuhan dari sisi dosen yang sudah memanfaatkan TI dalam proses pembelajaran.

2. Data kebutuhan dari sisi mahasiswa yang sudah memanfaatkan TI dalam proses pembelajaran.

Data mahasiswa yang diambil sebagai sampel berjumlah 70 mahasiswa, sedangkan 
untuk data sampel dari dosen berjumlah lima orang yang masing-masing mewakili program studi yang telah ditetapkan dalam penelitian ini.

Data yang didapatkan dari mahasiswa berbentuk hardcopy dan softcopy yang disebar di kelas serta melalui google-form. Hasil dari pengumpulan data responden mahasiswa melalui kuesioner dengan kategori program studi yaitu mahasiswa dari program studi Psikologi, program studi Informatika, program studi Pendidikan Agama Islam dan program studi Kimia. Total data kuesioner yang terkumpul yaitu 70 data.

Kategori dalam kuesioner dibedakan dari program studi, responden mahasiswa terbagi dari empat kategori program studi yaitu program studi Psikologi, program studi Informatika, program studi Pendidikan Agama Islam dan program studi Kimia. Jumlah responden sesuai kategori program studi tersaji pada Tabel 2.

Tabel 2 Jumlah responden kategori program studi

\begin{tabular}{clc}
\hline No. & Program Studi & Jumlah \\
\hline 1 & Psikologi & 15 \\
2 & Informatika & 25 \\
3 & Pendidikan & 15 \\
& Agama Islam & \\
4 & Kimia & 15 \\
\hline \multicolumn{2}{c}{ TOTAL } & 70 \\
\hline
\end{tabular}

Data kualitatif didapat dari wawancara kepada responden dosen yang terdiri dari lima dosen, satu perwakilan dosen dari program studi Pendidikan Agama Islam, satu dosen dari program studi Pendidikan Kimia, satu dosen dari program studi Psikologi, serta dua dosen dari program studi Informatika.

Proses desain dan pengembangan model gamification menggunakan kerangka MDA (Mechanics Dynamics Aesthetic) yang merupakan sumber dasar dari model elemen gamification (Hamzah, Ali, Saman, Yusoff, \&
Yacob, 2015). MDA bertindak sebagai penghubung yang mampu memunculkan banyak aspek yang terkait dengan proses pembelajaran sebagai dasar perancangan aplikasi, seperti aspek challenge hingga aspek curiosity (Deterding, Dixon, Khaled, \& Nacke, 2011).

Analisis berbagai model gamification dalam dunia pendidikan dengan menggunakan kerangka MDA telah dilakukan oleh Kusuma, Wigati, Utomo, \& Suryapranata (2018) dan menghasilkan rangkuman variasi model gamification dalam kerangka MDA. Model-model variasi gamification berdasarkan kerangka MDA dari segi game mechanics dapat dilihat pada Tabel 3. 
Tabel 3. Variasi mechanics pada model gamification (Kusuma, Wigati, Utomo, \& Suryapranata, 2018)

\begin{tabular}{lll}
\hline No. & \multicolumn{1}{c}{ Tipe } & \multicolumn{1}{c}{ Mechanics } \\
\hline 1 & Player progression & Point (Score) \\
& Achievement (badges, trophies, \\
& reward system) \\
& Leaderboard \\
& Levels (Level up system) \\
& Missions (quest, optional assignment, mission selection, \\
& collect object) \\
& Minigame (Quiz, Puzzle) \\
& Role-playing \\
& Unique Controller \\
& Simulation \\
& Drag and drop \\
& Turn-based \\
& Feedback \\
& Map \\
& Background Story \\
& Characters \\
& GPS location \\
& Obstacle and enemies \\
& Tutorials \\
& Social media platform (chat \\
& feature or forum) \\
& Items \\
& Increasing difficulty \\
& Tooltips and hints \\
& Augmented reality \\
& Virtual Reality \\
&
\end{tabular}

Model-model gamification berdasarkan kerangka MDA dari segi game dynamics dengan telah dilakukan juga oleh Kusuma, Wigati, Utomo, \& Suryapranata (2018) dan menghasilkan 12 variasi model gamification yaitu tipe receive badges, achievement, or other rewards, tipe role-playing, tipe nonlinear progression, tipe real exploration, tipe in-game exploration, tipe puzzle solving, tipe difficulty adjustment, tipe hints, tipe management - simulation, tipe turn - based, tipe adaptation system, serta tipe quiz system.

Model-model variasi gamification berdasarkan kerangka MDA dari segi aesthetics yang telah dirangkum oleh Kusuma, Wigati, Utomo, \& Suryapranata (2018) menghasilkan delapan variasi model gamification dari segi aesthetics yaitu tipe sensation, tipe challenge, tipe fellowship, tipe discovery, tipe fantasy, tipe narrative, tipe expression dan tipe submission.

\subsubsection{Demonstrasi}

Tahapan ini berupa uji coba aplikasi yang sudah dikembangkan kepada pengguna, yaitu masing-masing dosen dari empat program studi sarjana serta empat mahasiswa dari empat program studi yang berbeda. Pengguna diminta menjalankan aplikasi yang dirancang kemudian memberikan tanggapan dan masukan terhadap aplikasi.

\subsubsection{Evaluasi}

Dalam tahapan ini, dilakukan analisis terhadap masukan dan penilaian dari 
pengguna setelah mencoba aplikasi secara langsung. Hasil penilaian pengguna dijadikan sebagai dasar evaluasi terhadap aplikasi yang dikembangkan untuk ditambah atau diperbaiki fiturnya.

\subsubsection{Publikasi}

Pada tahapan ini, aplikasi sudah selesai diuji dan telah melalui evaluasi. Aplikasi kemudian dinyatakan siap dirilis di lingkungan universitas dan digunakan di kelas-kelas untuk mendukung proses pembelajaran interaktif.

\section{Hasil dan Pembahasan}

\subsection{Responden Mahasiswa}

\subsubsection{Uji Validasi}

Proses uji validitas kuesioner berdasarkan rumus korelasi produk moment (Sugiyono, 2005). Pengujian menggunakan SPSS versi 22. Pengujian menghasilkan nilai $r$ _hitung tiap pertanyaan lebih besar daripada nilai r_tabel yaitu 0.2352 dengan nilai signifikansi 0.05 (Ghozali, 2005). Dengan demikian, dapat disimpulkan bahwa seluruh pertanyaan dianggap valid, sehingga kuesioner dapat dipakai untuk proses analisis lebih lanjut.

\subsubsection{Uji Realiabilitas}

Proses uji reliabilitas kuesioner menggunakan teknik Cronbach's alpha. Pengujian menghasilkan nilai Cronbach's alpha adalah 0.857 . Karena nilai Cronbach's alpha lebih besar daripada 0.6, kuesioner dapat dinyatakan reliabel (Sujarweni, 2015).

\subsubsection{Hasil Kuesioner}

Melalui beberapa proses yang telah dilakukan sebelumnya maka didapatlah hasil kuesioner yang bisa dilihat pada Gambar 3 . Gambar 3 menunjukkan hasil pengukuran variabel kuesioner.

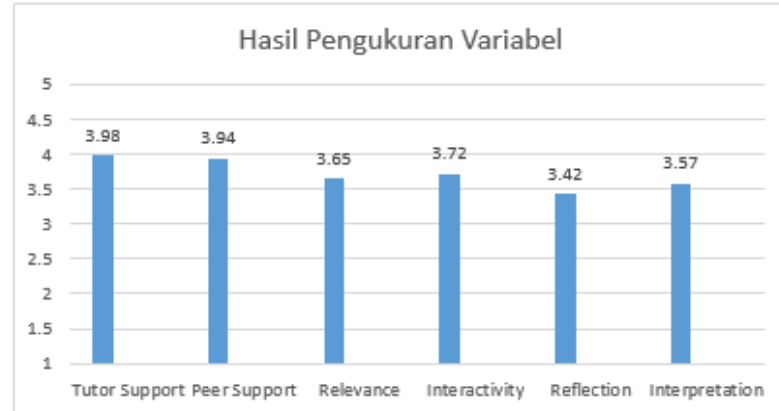

Gambar 3. Hasil Pengukuran Variabel

Variabel Tutor Support mendapat nilai rata-rata 3.98. Hal ini berarti bahwa dukungan dosen untuk mewujudkan peran aktif mahasiswa dalam proses perkuliahan menggunakan TI dalam bentuk diskusi dan berbagi pengetahuan sudah siap, namun masih perlu beberapa perbaikan.

Variabel Peer Support mendapatkan nilai rata-rata 3.94. Hal ini berarti bahwa dukungan antar mahasiswa dalam forum diskusi, kerjasama, kerja kelompok dan iklim kompetisi di kelas menggunakan TI sudah siap, namun masih perlu sedikit perbaikan.

Variabel Relevance mendapatkan nilai rata-rata 3.65. Hal ini berarti bahwa kesesuaian TI yang digunakan dan tingkat pemahaman/pengetahuan mahasiswa sudah siap, namun perlu sedikit perbaikan.

Variabel Interactivity mendapatkan nilai rata-rata 3.72. Hal ini berarti bahwa tingkat partisipasi mahasiswa pada proses berbagi pengetahuan menggunakan TI sudah siap, namun masih perlu sedikit perbaikan.

Variabel Reflection mendapatkan nilai rata-rata 3.42. Hal ini mengindikasikan belum siapnya aplikasi untuk meningkatkan minat mahasiswa dalam berfikir kritis serta berwawasan dan pandangan terbuka, sehingga perlu kerja keras untuk mencapai keberhasilan dalam penerapan aplikasi nantinya.

Variabel Interpretation mendapatkan nilai rata-rata 3.57. Hal ini berarti bahwa pemahaman dosen dan mahasiswa dalam berkomunikasi melalui TI sudah siap, namun masih perlu sedikit perbaikan.

Hasil tersebut menggambarkan bahwa mahasiswa cukup aktif karena mendapat 
dukungan dari dosen yang memberikan kesempatan dalam bentuk diskusi dan berbagi pengetahuan dalam kelas. Dukungan dari sesama mahasiswa juga menjadi faktor penting dalam proses pembelajaran sehingga diskusi, pertukaran pengetahuan, kerjasama kelompok, serta iklim persaingan antar mahasiswa berjalan dengan baik. Partisipasi mahasiswa dalam proses pertukaran pengetahuan menggunakan TI juga baik, karena mahasiswa dapat mengukur secara langsung kemampuannya yang dilakukan di kelas dengan TI. Komunikasi antar dosen dengan mahasiswa menggunakan TI terjalin dengan baik, di mana keduanya memiliki pemahaman yang sama, mulai dari perhitungan prioritas tugas yang harus diselesaikan terlebih dahulu.

Nilai terendah terdapat pada variabel Reflection yaitu 3.42 yang mengindikasikan belum siap dan memerlukan kerja keras dalam penerapannya nanti. Hal ini dikarenakan sistem belum mampu membangkitkan mahasiswa untuk berfikir kritis serta terbuka dalam menyampaikan ketidakpahaman materi saat proses perkuliahan berlangsung. Diperlukan pelatihan serta bimbingan dari dosen bagi mahasiswanya terkait kesulitan yang dihadapi selama proses pembelajaran.

\subsection{Responden Dosen}

Dosen 1 dari Program Studi Pendidikan Agama Islam telah sesekali menggunakan $e$ learning dalam proses pembelajaran serta penilaian pembelajaran individu dan kelompok. Dosen 1 membutuhkan aplikasi yang mudah diakses oleh penggunanya, memudahkan dosen dalam melakukan penilaian presentasi, memudahkan dosen merekap nilai, dan memungkinkan mahasiswa melihat hasilnya. Dosen 1 belum memiliki pengalaman menerapkan gamification dalam proses pembelajaran di kelas.

Dosen 2 dari Program Studi Psikologi menggunakan google classroom untuk mengakomodasi pengumpulan tugas mahasiswa dan menggunggah materi kuliah. Kelemahan yang dirasakan selama ini adalah aplikasi tidak bisa secara interaktif menjembatani interaksi dosen dan mahasiswa. Kendala penggunaan google classroom dalam proses pembelajaran saat diakses melalui smartphone terkait berjalannya memory yang besar sehingga sering terjadi materi tidak terbarui atau bahkan hilang. Dosen 2 membutuhkan aplikasi yang terintegrasi, mampu menampilkan pencapaian pembelajaran mahasiswa, dan ramah pengguna. Dosen 2 telah memiliki pengalaman gamification melalui penggunaan Kahoot, yaitu game elements leaderboards saat melakukan kuis di kelas.

Dosen 3 dari Program Studi Pendidikan Kimia tidak selalu menggunakan google classroom dan hanya menggunakannya di waktu tertentu saja. Kendala yang dialami adalah proses penilaian tugas yang masih secara manual diteliti tiap nomer dari pekerjaan mahasiswa serta minat belajar mahasiswa yang kurang. Dosen 3 membutuhkan aplikasi yang memberi kemudahan dalam proses menilai tugas mahasiswa dengan skala dan rubrik nilai, serta menyimpan hasilnya, sehingga memudahkan saat merekap nilai di akhir semester. Dosen 3 juga memerlukan fitur kuis yang mampu meningkatkan partisipasi mahasiswa. Dosen 3 telah memiliki pengalaman gamification, dengan menggunakan Kahoot dan Mentimeter.

Dosen 4 dari Program Studi Informatika menggunakan TI untuk memberi gambaran materi yang akan dipelajar dan membentuk kelompok belajar/diskusi dalam kelas. Konten belajar berupa slide presentasi, buku, tugas baik individu maupun kelompok, serta pembelajaran online. Dosen 4 mengharapkan aplikasi untuk penilaian presentasi dengan grade nilai berdasarkan kriteria mulai dari tampilan hingga pembawaan materi, disertai catatan. Dosen 4 mempunyai pengalaman gamification menggunakan Kahoot.

Dosen 5 dari Program Studi Informatika menerapkan pembelajaran untuk orang dewasa, dimana mahasiswa melakukan pembelajaran lebih dulu dari apa yang 
dimiliki. Pemberian tugas dilakukan untuk memaksa mahasiswa belajar dan memberi feedback. Dosen mengkonfirmasi apa yang kemudian dipahami mahasiswa. Dosen 5 membutuhkan aplikasi untuk penilaian tiap tugas yang memudahkan merekap di akhir semester. Dosen 5 memiliki pengalaman gamification dengan menerapkan Kahoot saat melakukan kuis di kelas.

Terkait pengalaman dosen dalam menerapkan gamification dalam pembelajaran di kelas, empat dari lima dosen telah memiliki pengalaman menerapkannya antara lain dengan Kahoot dan Mentimeter. Pengalaman dan penilaian positif dosen terhadap penggunaan aplikasi gamification menjadi dasar bagi penelitian ini untuk merancang model aplikasi gamification pada smartphone untuk pembelajaran di kelas.

Berdasarkan hasil wawancara, diperoleh kebutuhan aplikasi sebagai berikut: kemudahan akses saat memasuki sistem, kemudahan akses materi, sistem yang ramah pengguna, serta tersedia proses penilaian mahasiswa berdasar kriteria, pemberian nilai dan catatan sebagai bahan evaluasi kedepannya nanti.

\subsection{Analisis Gabungan}

Hasil konfirmasi mahasiswa mengenai bentuk komunikasi pembelajaran menggunakan TI, dan pengalaman dosen dalam penggunaan gamification, serta kebutuhan aplikasi dijadikan dasar membangun model aplikasi gamification pada smartphone. Gamification yang diterapkan pada model aplikasi ini menggunakan beberapa game elements yang terdiri dari experience point, level untuk setiap mahasiswa, leaderboard dan badges. Penyertaan game elements tersebut berdasarkan hasil kuesioner kepada mahasiswa. Pemilihan game elements ini bertujuan untuk meningkatkan partisipasi serta minat belajar mahasiswa saat proses perkuliahan (Barata, Gama, Jorge, \& Goncalves, 2013).

\subsection{Analisis Mechanics Dynamics Aesthetics (MDA) dalam Model Gamification pada Rancangan Aplikasi}

Pada penelitian ini, tiga tipe komponen mechanics yang digunakan adalah player progression, tasks dan additional features.

Dengan tipe player progression, aplikasi ini akan menampilkan point, achievement yaitu berupa badges, level, dan leaderboard. Tipe task diterapkan berupa quiz. Kombinasi player progression terutama poin, level, dan badges serta menampilkannya pada leaderboard setelah mahasiswa menyelesaikan quiz akan membuat lingkungan serta suasana belajar menjadi kompetitif dan pengguna pun akan berlomba menjadi yang terbaik (Kusuma, Wigati, Utomo, \& Suryapranata, 2018).

Tipe additional features diterapkan berupa avatar dan feedback. Avatar diterapkan dengan tujuan memberi keleluasaan dan ruang pribadi bagi pengguna yang menyalurkan kreativitas dan kebebasan dalam memasang profile picture personalnya. Feedback diterapkan pada penilaian presentasi mahasiswa baik individu maupun kelompok. Feedback memudahkan dalam melakukan evaluasi secara langsung berdasarkan hasil penilaian tersebut (Fischer, Heinz, Schlenker, \& Follert, 2016).

Penelitian-penelitian sebelumnya juga telah menerapkan game mechanics tersebut sebagaimana dapat dilihat pada Tabel 4 .

Pada penelitian ini, dua tipe komponen dynamics yang digunakan adalah receive badges, achievement, or other rewards dan quiz system.

Penggunaan komponen dynamics receive badges, achievement, or other rewards akan memberikan hadiah atau rewards bagi mahasiswa setelah menyelesaikan tugastugasnya berupa badges. Pemberian rewards akan berdampak positif yakni meningkatkan motivasi untuk mempertahankan apa yang diraih dan meningkatkannya melalui strategi masing-masing (Kusuma, Wigati, Utomo, \& Suryapranata, 2018). Komponen dynamics selanjutnya yaitu quiz system berupa quiz dipilih karena memiliki efek yaitu dapat 
meningkatkan proses pembelajaran berupa pemahaman/ penalaran mahasiswa yang lebih mendalam pada materi perkuliahan serta meningkatkan hasil retensi (Sanchez, Langer, \& Kaur, 2020).

Penelitian-penelitian sebelumnya yang menerapkan game dynamics dapat dilihat pada Tabel 5.

Pada penelitian ini, dua tipe komponen aesthetics yang digunakan adalah sensation dan challenge. Aplikasi gamification harus memberikan efek berupa sensasi ketertarikan dari para pengguna yang diakibatkan dari bentuk pembelajaran yang interaktif (Kusuma, Wigati, Utomo, \& Suryapranata, 2018). Penerapan challenges atau tantangan ini akan memberikan tujuan kepada mahasiswa untuk mencari cara dan berusaha menyelesaikan tantangan sebagai motivasi untuk terus belajar (Kusuma, Wigati, Utomo, \& Suryapranata, 2018).

Beberapa penelitian sebelumnya yang menerapkan tipe aesthetic dapat dilihat pada Tabel 6.

Tabel 4. Game mechanics dalam rancangan aplikasi ini

\begin{tabular}{|c|c|c|c|}
\hline No. & Tipe & Mechanics & Referensi \\
\hline \multirow[t]{4}{*}{1} & \multirow[t]{4}{*}{$\begin{array}{c}\text { Player } \\
\text { progression }\end{array}$} & Point & $\begin{array}{l}\text { (Hew, Huang, Chu, \& Chiu, 2016), (Rajšp, Beranič, Heričko, \& } \\
\text { Horng-Jyh, 2017), (Dicheva, Irwin, \& Dichev, 2018). }\end{array}$ \\
\hline & & Badges & $\begin{array}{l}\text { (da Rocha Seixas, Gomes, \& de Melo Filho, 2016), (Hamari, } \\
\text { 2017), (Zhou, Chen, Fan, \& Ji, 2019). }\end{array}$ \\
\hline & & Level & $\begin{array}{l}\text { (Matsubara \& Da Silva, 2017), (Annansingh, 2018), (Dicheva, } \\
\text { Irwin, \& Dichev, 2018). }\end{array}$ \\
\hline & & Leade & $\begin{array}{l}\text { (Alexander, 2017), (Höllig, Tumasjan, \& Welpe, 2018), (Ortiz- } \\
\text { Rojas, Chiluiza, \& Valcke, 2019). }\end{array}$ \\
\hline 2 & Task & Quiz & $\begin{array}{l}\text { (Le Maire, Dalcq, Colaux-Castillo, Fauconnier, \& Verpoorten, } \\
\text { 2017), (Orte, Ruedes, Cruz, Conejo, Paredes, Crovetto, \& } \\
\text { Miguel, 2019), (Wilkinson, Dafoulas, Garelick, \& Huyck, 2020). }\end{array}$ \\
\hline \multirow[t]{2}{*}{3} & \multirow[t]{2}{*}{$\begin{array}{l}\text { Additional } \\
\text { features }\end{array}$} & Avatar & $\begin{array}{l}\text { (Nah, Telaprolu, Rallapalli, \& Venkata, 2013), (Featherstone, } \\
\text { 2016), (Sailer, Hense, Mandl, \& Klevers, 2017). }\end{array}$ \\
\hline & & Feedback & $\begin{array}{l}\text { (Schneider, Janson, \& Schöbel, 2018), (Huang, Hwang, Hew, \& } \\
\text { Warning, 2019). }\end{array}$ \\
\hline
\end{tabular}

Tabel 5. Game dynamics dalam rancangan aplikasi ini

\begin{tabular}{|c|c|c|c|}
\hline No. & Tipe & Dynamics & Referensi \\
\hline 1 & $\begin{array}{l}\text { Receive badges, } \\
\text { achievement, or other } \\
\text { rewards }\end{array}$ & Badges & $\begin{array}{l}\text { (Loos \& Crosby, 2017), (Rajšp, Beranič, Heričko, \& } \\
\text { Horng-Jyh, 2017), (Zhou, Chen, Fan, \& Ji, 2019). }\end{array}$ \\
\hline 2 & Quiz system & Quiz & $\begin{array}{l}\text { (Le Maire, Dalcq, Colaux-Castillo, Fauconnier, \& } \\
\text { Verpoorten, 2017), (Garcia-Sanjuan, Jurdi, Jaen, \& } \\
\text { Nacher, 2018), (Sanchez, Langer, \& Kaur, 2020). }\end{array}$ \\
\hline
\end{tabular}


Tabel 6 Game aesthetics dalam rancangan aplikasi ini

\begin{tabular}{ccl}
\hline No. & $\begin{array}{c}\text { Tipe } \\
\text { Aesthetics }\end{array}$ & \multicolumn{1}{c}{ Referensi } \\
\hline 1 & Sensation & $\begin{array}{l}\text { (Loos \& Crosby, 2017), (Annansingh, 2018), (Zhou, Chen, Fan, \& Ji, } \\
\text { 2019). } \\
\text { (Alexander, 2017), (Mader \& Bry, 2018), (Sanchez, Langer, \& Kaur, } \\
\text { 2020). }\end{array}$ \\
\hline
\end{tabular}

\subsection{Deskripsi Dynamics pada Model Aplikasi Gamification}

Rancangan model aplikasi gamification ini terdiri dari beberapa game elements berdasarkan hasil analisis kuesioner. Game elements yang pertama yaitu experience point dipilih berdasarkan variabel interactivity dengan indikator berupa mahasiswa mampu mengukur kemajuan dan pemahaman terhadap materi kuliah. Experience point akan didapat mahasiswa setelah menyelesaikan dan berdasarkan hasil nilai kuis, tugas atau presentasi. Pemberian point merupakan ukuran atas hasil pencapaian penyelesaian tugas. Poin akan terakumulasi sehingga akan menghasilkan posisi yang memberikan kebanggaan bagi mahasiswa di lingkup kelasnya (Mekler, Brühlmann, Opwis, \& Tuch, 2013). Experience point ini berhubungan dengan peningkatan pada game elements lainnya yaitu level.

Game element yang kedua yaitu level juga berdasarkan variabel interactivity dengan indikator berupa mahasiswa mampu mengukur kemajuan dan pemahaman terhadap materi kuliah. Level akan meningkat apabila mahasiswa telah menyelesaikan tugas dan mahasiswa akan mendapatkan poin. Poinpoin yang terkumpul akan meningkatkan level mahasiswa. Poin yang harus didapatkan untuk berpindah dari satu level ke level selanjutnya yaitu 25 poin. Level tersebut menggambarkan tingkat kemajuan serta ketercapaian pembelajaran. Selain itu level juga menjadi sebuah penghargaan bagi mahasiswa setelah berhasil menyelesaikan tugas yang diberikan (Goehle, 2013).

Game elements yang ketiga yaitu leaderboard, dipilih berdasarkan variabel peer support dan interactivity. Indikatornya berupa mahasiswa berkompetisi dengan mahasiswa lain di kelas dengan penilaian peringkat pada tugas/kuis. Leaderboard akan tampil saat mahasiswa telah menyelesaikan kuis. Dosen dan semua mahasiswa dapat melihat peringkat mahasiswa berdasarkan nilai kuisnya. Leaderboard berfungsi meningkatkan motivasi mahasiswa berkompetisi mencapai nilai terbaik dan mencapai puncak di antara mahasiswa lainnya. Fungsi ini untuk membuat suasana belajar yang kompetitif antar mahasiswa di kelas (O’Donovan, Gain, \& Marais, 2013).

Game elements yang terakhir yaitu badges juga dipilih berdasarkan variabel interactivity dengan indikator berupa mahasiswa mampu mengukur kemajuan dan pemahaman terhadap materi kuliah, serta variabel interpretation dengan indikator berupa mahasiswa dapat melihat hasil perkuliahan dengan cepat dan melakukan evaluasi. Badges akan ditampilkan saat mahasiswa menyelesaikan satu level dan menuju level selanjutnya. Pada awal penggunaannya, mahasiswa akan mendapatkan bronze badges dengan. Badges ini terdiri dari tiga levels. Kenaikan badges membutuhkan 75 poin. Pemberian badges ini agar mahasiswa semakin termotivasi dalam proses belajar mereka di dalam kelas, yaitu pada segi keterlibatannya dalam kegiatan pembelajaran hingga soal ketepatan waktu menyelesaikan tugas yang diberikan (Gibson, Ostashewski, Flintoff, Grant, \& Knight, 2015).

\subsection{Desain dan Pengembangan Aplikasi Berdasarkan Hasil Analisis Data}

Penjelasan desain dan pengembangan rancangan hanya befokus pada proses gamification saja. Tahap ini 
mempertimbangkan interaksi dan model pembelajaran yang selama ini terjadi di kelas berdasarkan kuesioner kepada mahasiswa, serta kendala dan kebutuhan yang diperlukan untuk mendukung proses pembelajaran di kelas berdasarkan wawancara kepada dosen.

\subsubsection{Rancangan tampilan experience point}

Poin akan didapatkan mahasiswa setelah menyelesaiakan kuis, tugas serta presentasi. Nilai poin ini akan mempengaruhi hasil pada fitur level serta badges. Poin diberikan di setiap kelas yang diikuti oleh mahasiswa. Poin akan bertambah sesuai dengan capaian pembelajaran di masing-masing kelas. Experience point ini termasuk dalam game aesthetics sensation. Tampilannya dapat dilihat pada Gambar 4.
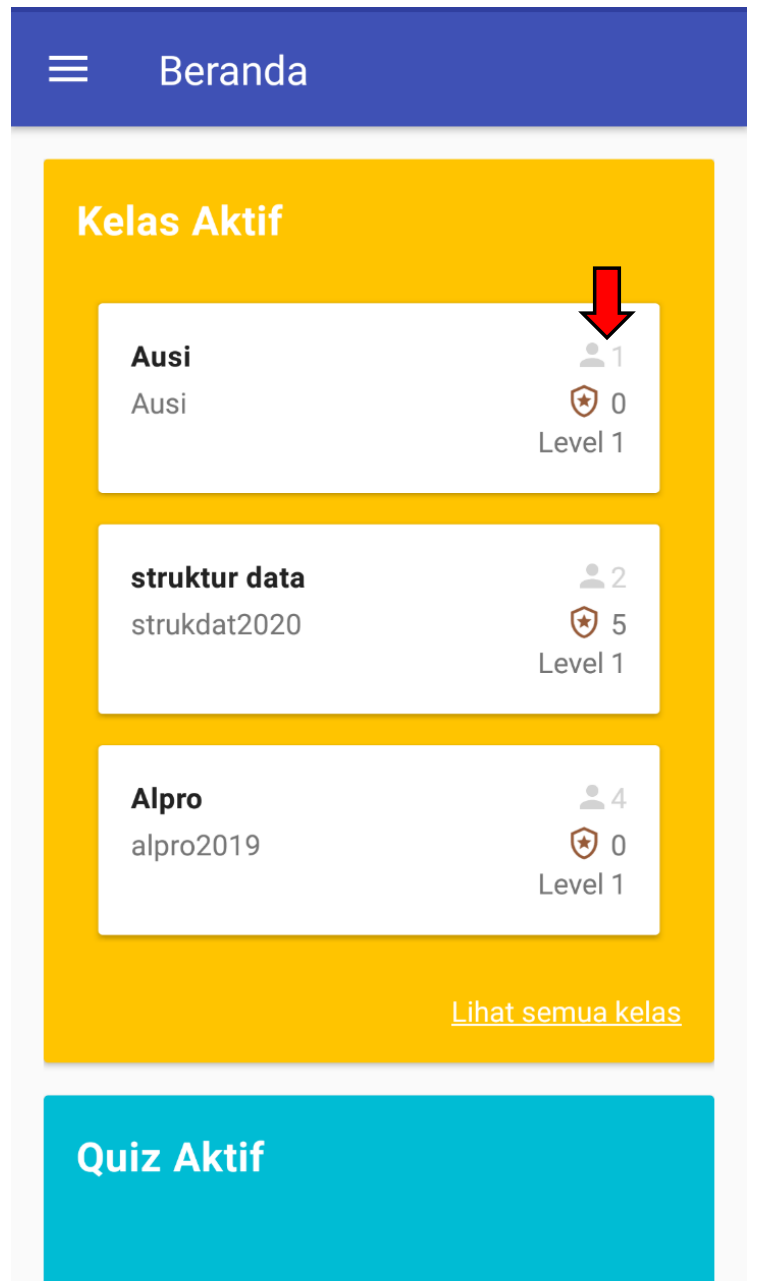

Gambar 4. Tampilan experience point

\subsubsection{Rancangan tampilan level}

Setelah menyelesaikan kuis, tugas atau presentasi, mahasiswa akan mendapatkan poin. Untuk naik ke level selanjutnya, mahasiswa harus mendapatkan 25 poin di setiap levelnya. Level maksimal adalah level 3. Level akan mempengaruhi hasil pada fitur badges. Level ini termasuk dalam game aesthetics sensation. Tampilannya dapat dilihat pada Gambar 5.

\subsubsection{Rancangan tampilan quiz.}

Kuis dibuat oleh dosen untuk dikerjakan oleh para mahasiswa sebagai dasar perolehan poin untuk menentukan level, badges hingga leaderboard yang akan tampil setelah mahasiswa menyelesaikan kuis. Kuis berupa soal pilihan ganda. Tiap soal dapat memiliki poin yang berbeda sebagaimana ditentukan oleh dosen. Kuis mempunyai batas waktu pengerjaan. Quiz ini termasuk dalam game aesthetics challenges. Tampilannya dapat dilihat pada Gambar 6.

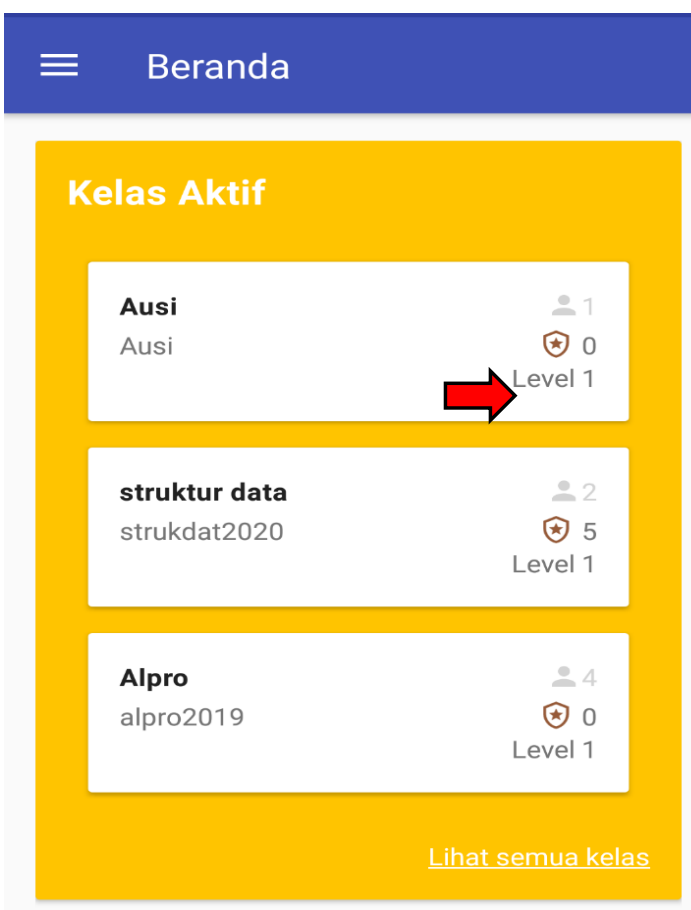

\section{Quiz Aktif}

Gambar 5. Tampilan level 


$\leftarrow \quad 07: 55: 34$
apakah nama aplikasi perancangan ini
A. android studio
B. eclipes
C. corona sdk
D. github

Gambar 6. Tampilan quiz

\subsubsection{Rancangan tampilan leaderboard}

Hasil leaderboard akan tampil setelah mahasiswa menyelesaikan kuis. Leaderboard menunjukkan peringkat semua mahasiswa yang mengikuti kuis. Leaderboard ini termasuk dalam game aesthetics sensation dan challenges. Tampilannya dapat dilihat pada Gambar 7.

\subsubsection{Rancangan tampilan badges}

Badges yang diberikan kepada mahasiswa terdiri dari tiga tipe, yakni: badges bronze, badges silver dan badges gold. Tiap tipe badges terdiri dari tiga level. Mahasiswa dengan badges bronze yang ingin mencapai badges silver harus melalui tiga level terlebih dahulu dan mahasiswa dengan badges silver ingin mencapai badges gold harus melalui tiga level juga. Fitur badges ini terhubung dengan hasil dari fitur sebelumnya yaitu poin

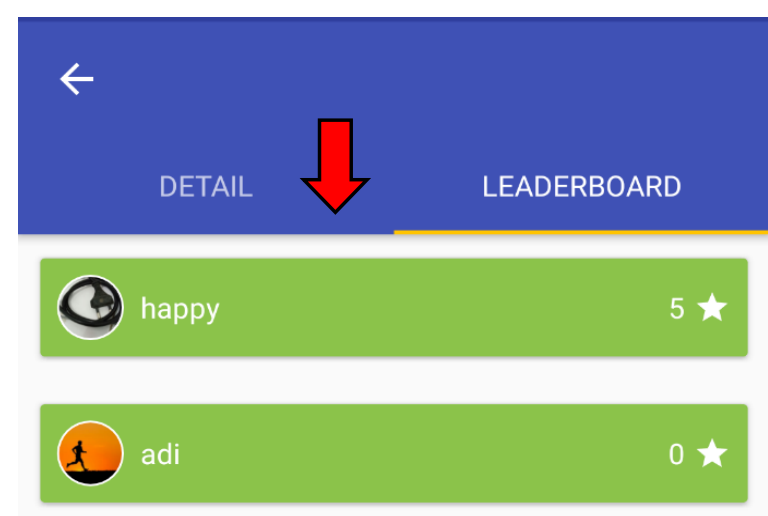

dan level. Badges ini termasuk dalam game aesthetics sensation. Tampilannya dapat dilihat pada Gambar 8.

\subsubsection{Rancangan tampilan avatar}

Avatar merupakan fitur yang termasuk dalam game mechanic.Avatar diberikan kepada setiap akun mahasiswa dan dosen dengan tujuan memberi kebebasan bagi pengguna untuk memasang dan mengekspresikan diri melalui profile picture akun mereka. Fitur ini akan dijumpai saat pertama kali mendaftar akun pada aplikasi ini. Tampilannya dapat dilihat pada Gambar 9 dan Gambar 10. 


\section{$\equiv$ Beranda}

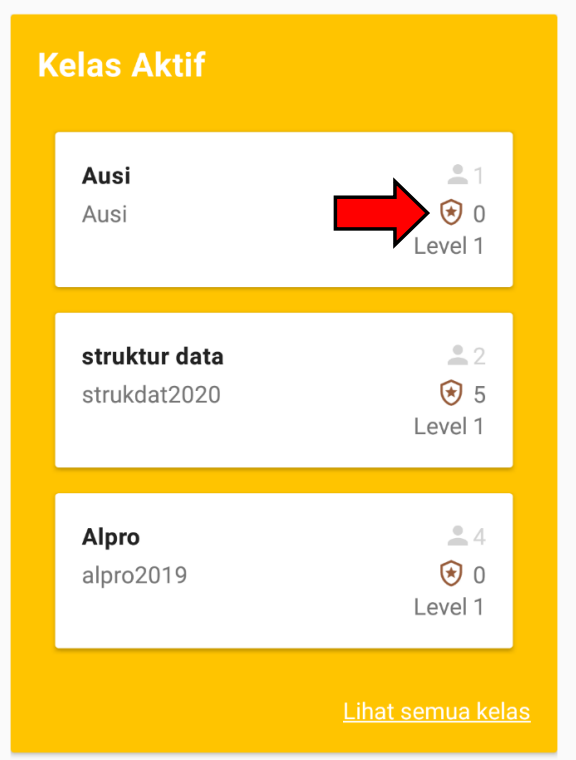

\section{Quiz Aktif}

Gambar 8. Tampilan badges

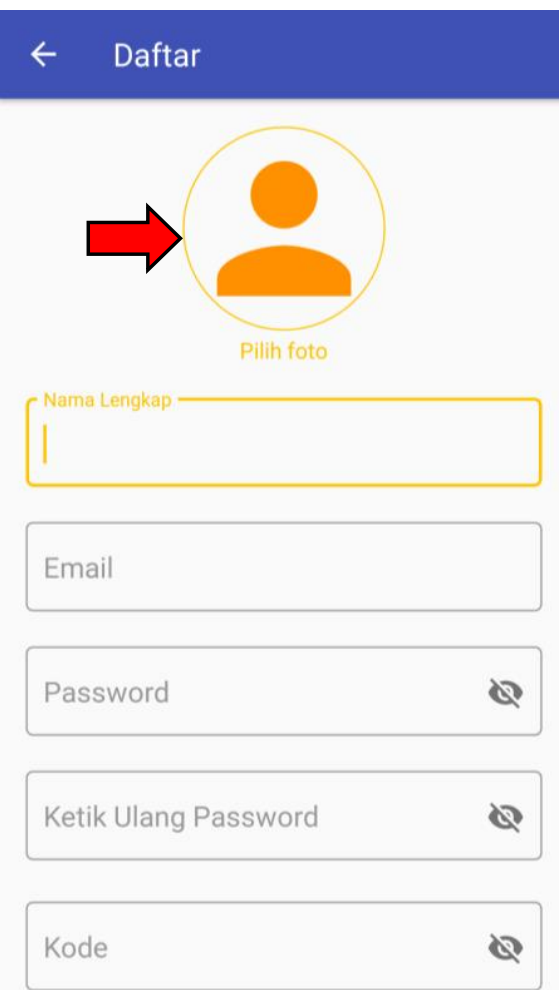

Gambar 9. Tampilan avatar pada halaman daftar

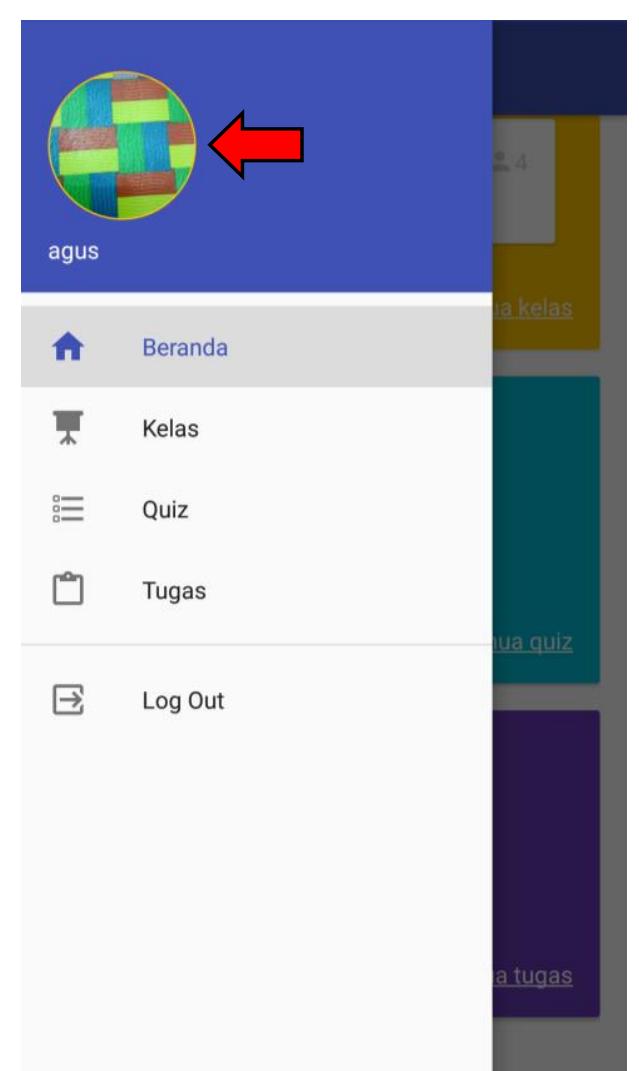

Gambar 10. Tampilan avatar pada halaman navigasi pengguna

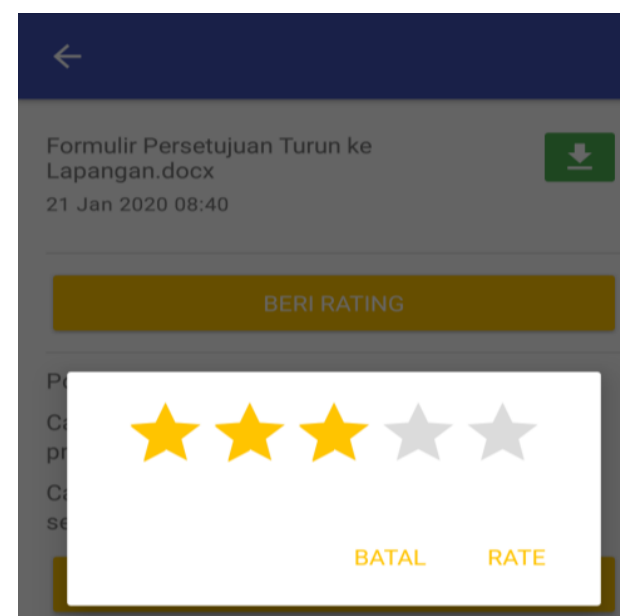

Gambar 11. Tampilan feedback pemberian rating 


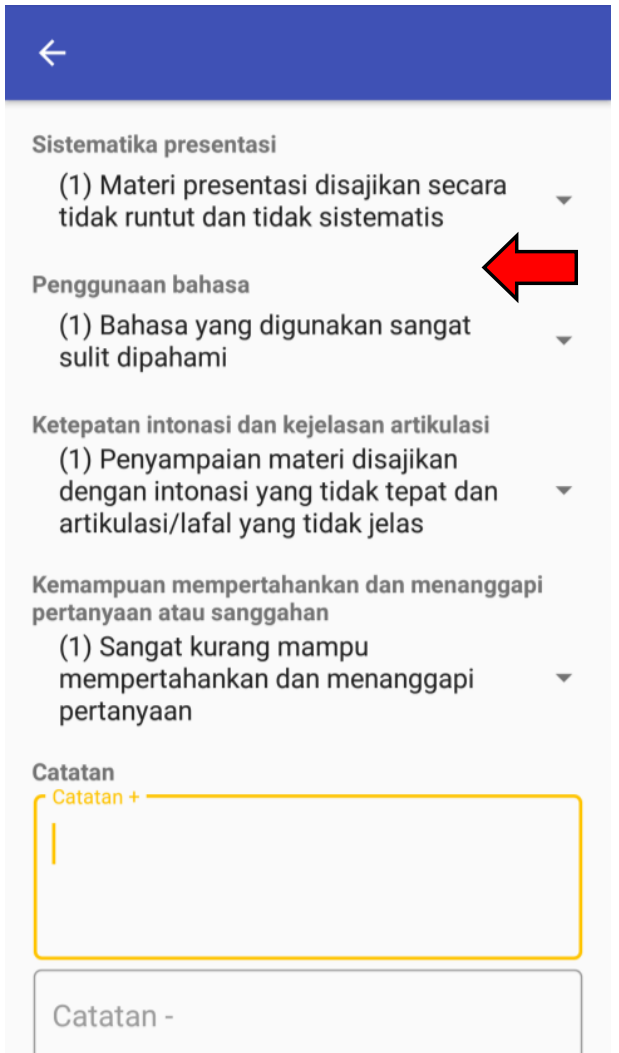

Gambar 12. Tampilan feedback untuk penilaian berdasarkan rubrik

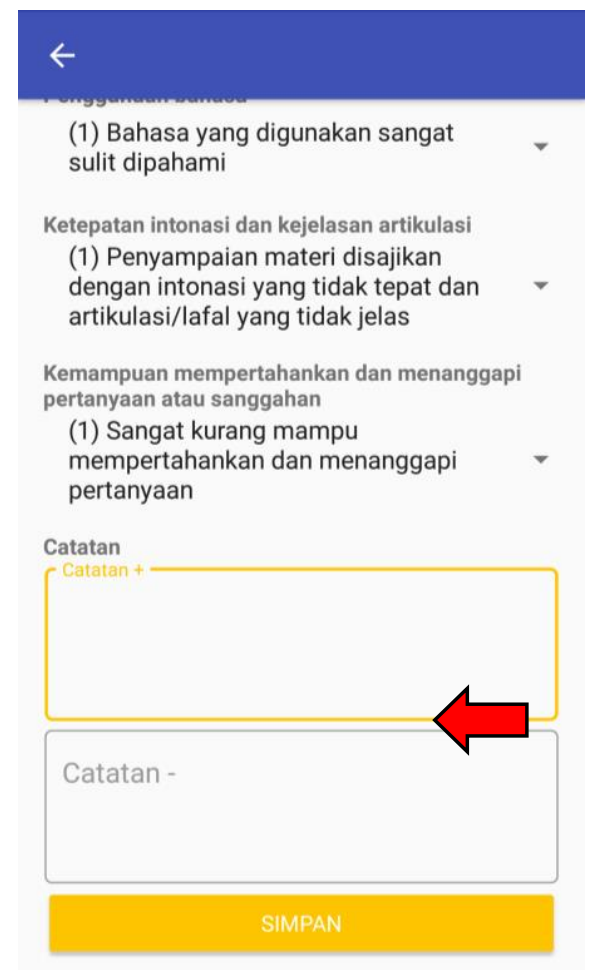

Gambar 13. Tampilan feedback untuk pemberian catatan

\subsubsection{Rancangan tampilan feedback}

Fitur feedback dijalankan oleh dosen untuk memberikan penilaian pada hasil kerja mahasiswa. Fitur feedback terdapat pada fitur tugas, khususnya untuk tugas presentasi baik dalam bentuk presentasi individu maupun presentasi kelompok. Pada fitur ini dosen dapat memberikan rating, poin berdasarkan rubrik, dan memberikan catatan masukan dan perbaikan. Feedback ini termasuk dalam game aesthetics sensation. Tampilannya dapat dilihat pada Gambar 11, Gambar 12 dan Gambar 13.

\subsection{Demonstrasi dan Evaluasi Rancangan Aplikasi pada Mahasiswa \\ Demonstrasi aplikasi dilakukan kepada} empat mahasiswa, masing-masing satu mahasiswa dari program studi Psikologi, Informatika, Pendidikan Agama Islam, serta Pendidikan Kimia.

Penilaian mahasiswa 1 adalah sebagai berikut. Fitur leaderboard berdampak meningkatkan motivasi untuk giat belajar meningkatkan nilai dan berkompetisi di kelas. Fitur level berdampak pada motivasi mengikuti proses pembelajaran dan bisa memantau berdasarkan capaian hasil pembelajaran. Fitur badges dinilai baik dan berdampak memberi motivasi semangat untuk meningkatkan hasil dan mencapai target belajar.

Penilaian mahasiswa 2 adalah sebagai berikut. Fitur leaderboard menjadikan proses pembelajaran lebih kompetitif dan memotivasi untuk mengerjakan kuis secara lebih maksimal agar mendapat nilai terbaik. Fitur level memberikan informasi tingkat pemahaman terhadap materi perkuliahan sekaligus dapat digunakan untuk evaluasi, menetapkan strategi belajar, dan meningkatkan level yang didapat. Fitur badges berdampak pada suasana proses pembelajaran di kelas yang lebih semangat, menarik, dan menantang karena adanya reward, serta membuat mahasiswa lebih fokus belajar. 
Penilaian mahasiswa 3 adalah sebagai berikut. Fitur leaderboard cukup membuat mahasiswa termotivasi dan menjadikan mahasiswa mengetahui kemampuannya sendiri. Fitur level berdampak memberikan semangat dan motivasi belajar serta membantu mahasiswa dalam mengetahui posisi dan kemampuannya. Fitur badges, berdampak pada meningkatnya semangat dan motivasi belajar.

Penilaian mahasiswa 4 adalah sebagai berikut. Fitur leaderboard cukup baik dan bagus karena fitur ini memberikan gambaran berupa nilai yang diperoleh dan perbandingannya terhadap mahasiswa lain sebagai evaluasi. Fitur level cukup baik karena bisa memantau seberapa kemampuan mahasiswa di mata kuliah tersebut. Fitur badges berdampak pada motivasi belajar dan menyelesaikan proses belajar dengan baik.

Melihat hasil data kualitatif kepada mahasiswa sebagai pengguna, dapat diambil kesimpulan bahwa fitur-fitur dalam aplikasi ini sudah cukup baik dalam menjawab permasalahan pembelajaran di kelas selama ini. Aplikasi ini dinilai cukup baik meningkatkan motivasi belajar, meningkatkan fokus belajar, dan memberikan gambaran capaian pembelajaran sehingga dapat digunakan untuk evaluasi strategi belajar agar mencapai target.

\subsection{Demonstrasi dan Evaluasi Rancangan Aplikasi pada Dosen}

Demonstrasi aplikasi dilakukan kepada lima dosen; masing-masing satu dosen dari program studi Pendidikan Agama Islam, Psikologi, Pendidikan Kimia, serta dua dosen dari program studi Informatika.

Dosen 1 dari program studi Pendidikan Agama Islam menilai bahwa aplikasi sudah ideal dan sempurna, namun perlu uji coba di kelas dengan jumlah mahasiswa yang sesungguhnya. Penggunaan aplikasi ini dinilai mudah, namun perlu sosialisasi dan panduan bagi pengguna sebagai pengenalan dalam menjalankan aplikasi. Aplikasi ini akan sangat membantu dalam penerapan proses pembelajaran dan mengeliminasi faktor yang dapat mengalihkan fokus mahasiswa selama proses pembelajaran. Fitur aplikasi dinilai sudah bagus dan mudah diaplikasikan, memfasilitasi model pembelajaran yang digunakan yaitu active learning dan study kritis.

Dosen 2 dari program studi Psikologi memberikan tanggapan dan penilaian terkait aplikasi ini. Secara umum, aplikasi dinilai sudah baik, namun perlu diuji dalam pemanfaatannya apakah aplikasi sudah menjawab kebutuhan proses pembelajaran. Dari sisi operasional aplikasi, fitur aplikasi mudah dijalankan dan mudah dipahami. Aplikasi bisa diterapkan di kelas sebagai alat bantu dengan catatan standar akademik dan kontrak nilai terkait akademik sudah disepakati. Aplikasi ini dinilai sudah mampu memfasilitasi kebutuhan proses pembelajaran, namun varian tugas perlu dikembangkan lagi.

Dosen 3 dari program studi Pendidikan Kimia menilai bahwa, secara umum, aplikasi sudah cukup bisa digunakan dan membantu dosen dalam melakukan pemberian materi, feedback hingga melihat pencapaian mahasiswa. Dari sisi operasional, aplikasi tergolong sangat mudah karena jelas nama menu-menunya dan mudah dipahami. Dari sisi penerapan dalam proses pembelajaran, aplikasi cukup memudahkan, walaupun tidak semua karakter matakuliah cocok menggunakan aplikasi ini. Aplikasi mampu membantu dosen dalam proses pembelajaran walaupun masih perlu beberapa tambahan dan pengembangan.

Dosen 4 dari program studi Informatika menilai bahwa, secara umum aplikasi ini masih dan varian kuis belum banyak sehingga masih memerlukan pengembangan. Dari sisi operasional, aplikasi masih banyak kendala. Aplikasi dirasa masih perlu pengembangan lagi untuk bisa dikatakan siap. Fitur aplikasi dinilai belum mampu memfasilitasi proses pembelajaran saat diterapkan dikelasnya.

Dosen 5 dari program studi Informatika menilai bahwa, secara umum, aplikasi sederhana dan cocok diterapkan di kelas 
yang diampu. Aplikasi dinilai mudah dipahami dan dioperasikan. Aplikasi cukup dapat membantu dan memudahkan dalam proses pembelajaran dengan adanya template penilaian.

Melihat hasil penilaian dari dosen sebagai pengguna, mayoritas dosen menilai aplikasi secara umum sudah baik dan cocok diterapkan. Dari sisi operasional, mayoritas dosen menilai bahwa aplikasi mudah digunakan. Mayoritas dosen menilai bahwa aplikasi cukup membantu dan memudahkan dalam proses pembelajaran. Fitur aplikasi memfasilitasi proses pembelajaran, namun masih perlu pengembangan lebih lanjut. Melihat penilaian tersebut dapat diambil kesimpulan bahwa rancangan aplikasi ini cukup baik dan memudahkan dalam menjawab permasalahan pada proses pembelajaran yang selama ini ditemui.

\section{Kesimpulan}

Pengukuran kesiapan pembelajaran berbasis perangkat smartphone yang ditujukan meningkatkan peran serta mahasiswa ini dapat menunjukkan bagian mana yang perlu di tingkatkan, dan bagian mana yang sudah baik namun perlu perbaikan dalam penerapannya. Untuk mewujudkan pembelajaran yang interaktif perlu pendekatan pembelajaran dengan model gamification, yang mampu meningkatkan motivasi dan keaktifan mahasiswa dalam kelas. Dari hasil analisis, dapat disimpulkan bahwa dukungan dari dosen pengampu mata kuliah yang memberikan kesempatan untuk mahasiswa dalam bentuk diskusi dan berbagi pengetahuan dalam kelas.

Partisipasi mahasiswa dalam pertukaran pengetahuan melalui TI juga baik dimana mahasiswa dapat mengukur secara langsung kemampuan, kemudahan memilih materi kuliah, serta peningkatan antusias terhadap tugas maupun kuis yang dilakukan di kelas. Komunikasi antar dosen dengan mahasiswa melalui TI terjalin dengan baik di mana keduanya memiliki pemahaman yang sama.

Hasil analisis memperlihatkan bagian yang masih membutuhkan perbaikan dan yang sudah baik berdasarkan nilai rata-rata variabel dan indikator yang diukur dengan model Aydın \& Tasci (2005). Hasil analisis ini menjadi dasar dalam menghasilkan rancangan model aplikasi gamification pada smartphone untuk pembelajaran di kelas. Aplikasi ini diharapkan memudahkan interaksi antara dosen dan mahasiswa, meningkatkan motivasi belajar, fokus, serta mencapai target yang diinginkan yaitu nilai yang terbaik dalam proses pembelajaran di kelas. Aplikasi juga memungkinkan mahasiswa melakukan evaluasi strategi belajar berdasarkan hasil yang diperoleh sebelumnya.

\section{Daftar Pustaka}

Alexander, C. (2017). Student perceptions of gamification in higher education. Society for Information Technology \& Teacher Education International Conference, 1428-1433. Association for the Advancement of Computing in Education (AACE).

Annansingh, F. (2018). An Investigation into the gamification of e-learning in higher education. In Gamification in Education: Breakthroughs in Research and Practice (pp. 174-190). IGI Global.

Awedh, M., Mueen, A., Zafar, B., \& Manzoor, U. (2015). Using Socrative and Smartphones for the support of collaborative learning. ArXiv Preprint ArXiv:1501.01276.

Aydın, C. H., \& Tasci, D. (2005). Measuring readiness for e-learning: Reflections from an emerging country. Journal of Educational Technology \& Society, 8(4), 244-257.

Barata, G., Gama, S., Jorge, J., \& Gonçalves, D. (2013). Engaging engineering students with gamification. 2013 5th International Conference on Games and Virtual Worlds for Serious Applications (VS-GAMES), 1-8. IEEE.

Chuang, Y.-T. (2015). SSCLS: A smartphone-supported collaborative 
learning system. Telematics and Informatics, 32(3), 463-474.

da Rocha Seixas, L., Gomes, A. S., \& de Melo Filho, I. J. (2016). Effectiveness of gamification in the engagement of students. Computers in Human Behavior, $58,48-63$.

Deterding, S., Dixon, D., Khaled, R., \& Nacke, L. (2011). From game design elements to gamefulness: defining" gamification". Proceedings of the 15th International Academic MindTrek Conference: Envisioning Future Media Environments, 9-15.

Dicheva, D., Irwin, K., \& Dichev, C. (2018). Motivational factors in educational gamification. 2018 IEEE 18th International Conference on Advanced Learning Technologies (ICALT), 408410. IEEE.

Effendy, O. U. (2008). Dinamika komunikasi. Remaja Rosdakarya.

Featherstone, M. (2016). Using gamification to enhance self-directed, open learning in higher education.

Ferrándiz, E., Puentes, C., Moreno, P. J., \& Flores, E. (2016). Engaging and assessing students through their electronic devices and real time quizzes. Multidisciplinary Journal for Education, Social and Technological Sciences, 3(2), 173-184.

Fischer, H., Heinz, M., Schlenker, L., \& Follert, F. (2016). Gamifying higher education. Beyond badges, points and Leaderboards. Knowledge Communities in Online Education and (Visual) Knowledge Management, 93.

Garcia-Sanjuan, F., Jurdi, S., Jaen, J., \& Nacher, V. (2018). Evaluating a tactile and a tangible multi-tablet gamified quiz system for collaborative learning in primary education. Computers \& Education, 123, 65-84.

Ghozali, I. (2005). Aplikasi Multivariate dengan program SPSS. Semarang: Badan Penerbit Universitas Diponegoro.

Gibson, D., Ostashewski, N., Flintoff, K., Grant, S., \& Knight, E. (2015). Digital badges in education. Education and
Information Technologies, 20(2), 403410.

Goehle, G. (2013). Gamification and webbased homework. Primus, 23(3), 234246.

Grinols, A. B., \& Rajesh, R. (2014). Multitasking with smartphones in the college classroom. Business and Professional Communication Quarterly, 77(1), 89-95.

Hamari, J. (2017). Do badges increase user activity? A field experiment on the effects of gamification. Computers in Human Behavior, 71, 469-478.

Hamzah, W. M. A. F. W., Ali, N. H., Saman, M. Y. M., Yusoff, M. H., \& Yacob, A. (2015). Influence of gamification on students' motivation in using e-learning applications based on the motivational design model. International Journal of Emerging Technologies in Learning (IJET), 10(2), 30-34.

Hew, K. F., Huang, B., Chu, K. W. S., \& Chiu, D. K. (2016). Engaging Asian students through game mechanics: Findings from two experiment studies. Computers \& Education, 92, 221-236.

Höllig, C. E., Tumasjan, A., \& Welpe, I. M. (2018). The interaction of trait competitiveness and leaderboard designan experimental analysis of effects on perceptions and usage intention. Proceedings of the 51st Hawaii International Conference on System Sciences.

Huang, B., Hwang, G.-J., Hew, K. F., \& Warning, P. (2019). Effects of gamification on students' online interactive patterns and peer-feedback. Distance Education, 40(3), 350-379.

Huang, W. H.-Y., \& Soman, D. (2013). Gamification of education. Report Series: Behavioural Economics in Action, 29.

Huotari, K., \& Hamari, J. (2012). Defining gamification: a service marketing perspective. Proceeding of the 16th International Academic MindTrek Conference, 17-22. 
Kim, E. K., Cho, J. E., \& Jung, E. C. (2009). The Study on Alternatives for Activating Communication Between Instructor and Students in Large Scale Lecture. J. Korea Soc. Design Forum, 22, 225-234.

Kim, Y., Jeong, S., Ji, Y., Lee, S., Kwon, K. H., \& Jeon, J. W. (2014). Smartphone response system using twitter to enable effective interaction and improve engagement in large classrooms. IEEE Transactions on Education, 58(2), 98103.

Krusche, S., Seitz, A., Börstler, J., \& Bruegge, B. (2017). Interactive learning: Increasing student participation through shorter exercise cycles. Proceedings of the Nineteenth Australasian Computing Education Conference, 17-26.

Kusuma, G. P., Wigati, E. K., Utomo, Y., \& Suryapranata, L. K. P. (2018). Analysis of gamification models in education using MDA framework. Procedia Computer Science, 135, 385-392.

Le Maire, N., Dalcq, A.-C., Colaux-Castillo, C., Fauconnier, M.-L., \& Verpoorten, D. (2017). Increasing gamification in a chemistry quiz: Comparative effects on performance, perceived competence, and the state of flow. International Journal of Technologies in Higher Education, 14(1), 69-83.

Loos, L. A., \& Crosby, M. E. (2017). Gamification methods in higher education. International Conference on Learning and Collaboration Technologies, 474-486. Springer.

Mader, S., \& Bry, F. (2018). Gaming the Lecture Hall: Using Social Gamification to Enhance Student Motivation and Participation. International Conference on Interactive Collaborative Learning, 555-566. Springer.

Matsubara, P. G. F., \& Da Silva, C. L. C. (2017). Game elements in a software engineering study group: a case study. 2017 IEEE/ACM 39th International Conference on Software Engineering: Software Engineering Education and
Training Track (ICSE-SEET), 160-169. IEEE.

Mekler, E. D., Brühlmann, F., Opwis, K., \& Tuch, A. N. (2013). Disassembling gamification: the effects of points and meaning on user motivation and performance. In CHI'13 extended abstracts on human factors in computing systems (pp. 1137-1142).

Nah, F. F.-H., Telaprolu, V. R., Rallapalli, S., \& Venkata, P. R. (2013). Gamification of education using computer games. International Conference on Human Interface and the Management of Information, 99-107. Springer.

O’Donovan, S., Gain, J., \& Marais, P. (2013). A case study in the gamification of a university-level games development course. Proceedings of the South African Institute for Computer Scientists and Information Technologists Conference, 242-251.

Orte, A., Ruedas, M. J., Cruz, O., Conejo, A., Paredes, J. M., Crovetto, L., ... GarcíaFernández, E. (2019). Gamification in the classroom: Mobile phones and online quizzes. FarmaJournal, 4(1), 103103.

Ortiz-Rojas, M., Chiluiza, K., \& Valcke, M. (2019). Gamification through leaderboards: An empirical study in engineering education. Computer Applications in Engineering Education, 27(4), 777-788.

Peffers, K., Tuunanen, T., Rothenberger, M. A., \& Chatterjee, S. (2007). A design science research methodology for information systems research. Journal of Management Information Systems, 24(3), 45-77.

Rajšp, A., Beranič, T., Heričko, M., \& Horng-Jyh, P. W. (2017). Students' Perception of Gamification in Higher Education Courses. Central European Conference on Information and Intelligent Systems, 69-75. Faculty of Organization and Informatics Varazdin.

Rifai, M. (2011). Sosiologi Pendidikan: struktur \& interaksi sosial di dalam 
institusi pendidikan. [Diterbitkan] dan didistribusikan oleh Ar-Ruzz Media.

Sailer, M., Hense, J., Mandl, H., \& Klevers, M. (2017). Fostering development of work competencies and motivation via gamification. In Competence-based Vocational and Professional Education (pp. 795-818). Springer.

Sanchez, D. R., Langer, M., \& Kaur, R. (2020). Gamification in the classroom: Examining the impact of gamified quizzes on student learning. Computers \& Education, 144, 103666.

Sanjaya, W. (2008). Kurikulum Dan Pembelajaran (Teori \& Praktek KTSP). Kencana.

Schneider, T., Janson, A., \& Schöbel, S. (2018). Understanding the Effects of Gamified Feedback in Mobile LearningAn Experimental Investigation.

Sugiyono, Y. (2005). Analisis StatistikaKorelasi Linier Sederhana.

Sujarweni, V. W. (2015). SPSS untuk Penelitian. Yogyakarta: Pustaka Baru Press.

Taylor, P., \& Maor, D. (2000). Assessing the efficacy of online teaching with the Constructivist Online Learning Environment Survey.

Wang, F., Hu, Y., \& Lin, L. (2019). Real-time Interaction Platform for Classroom Teaching Based on Smart Phone APP. Journal of Physics: Conference Series, 1168, 062024. IOP Publishing.

Wijaya, K. K. (2015, November 17). Studi Google mengenai tingkah laku pengguna smartphone Indonesia. Retrieved April 20, 2019, from Tech in Asia Indonesia website: https://id.techinasia.com/googlestudi-tingkah-laku-pengguna-smartphone

Wilkinson, K., Dafoulas, G., Garelick, H., \& Huyck, C. (2020). Are quiz-games an effective revision tool in Anatomical Sciences for Higher Education and what do students think of them? British Journal of Educational Technology, 51(3), 761-777.

Zhou, L., Chen, L., Fan, Q., \& Ji, Y. (2019). Students' perception of using digital badges in blended learning classrooms. Sustainability, 11(7), 2151. 